PENELITIAN

\title{
PENGARUH ANESTESI REGIONAL DAN GENERAL PADA SECTIO CESARIA PADA IBU DENGAN PRE EKLAMPSIA BERAT TERHADAP APGAR SCORE
}

\author{
Nurhadi Wijayanto*, Ery Leksana**, Uripno-Budiono** \\ *Bagian Anestesiologi RSU Bhayangkara Sartika Asih Bandung \\ **Bagian Anestesiologi dan Terapi Intensif FK Undip/ RSUP Dr. Kariadi, Semarang
}

\begin{abstract}
Background: in patients with severe preeclampsia intubation is dangerous because of the actions associated with airway management and hemodynamic fluctuations that may occur. Spinal anesthesia avoided many risks associated with hypotensive but some studies have shown that spinal anesthesia is safe for both mother and fetus. debate about the influence of general anesthesia and spinal anesthesia on Apgar score is something interesting. Some research suggests that there was no difference in anesthesia on both of them but other studies say that the appreciation of the general anesthesia will result in a lower than spinal anesthesia.
\end{abstract}

Objective: to compare the influence of general anesthesia and spinal anesthesia on children born to mothers with a sectio caesaria because of severe preeclampsia.

Methods: an experimental study design with prospective randomized control trial study, the research group is divided into two (n: 8), Group I is the group that received general anesthesia with pentothal $5 \mathrm{mg} / \mathrm{bb}$ dose and dose muscle paralytic suksinilkholis $1.5 \mathrm{mg} / \mathrm{bb}$ Conclusion: Apgar score in the group of spinal anesthetics are higher than general anesthesia in patients with sectio caesaria because of severe preeclampsia, but clinically by Apgar score categories of the two groups together

Key words: pre-eclampsia, Apgar score, spinal anesthesia, sectio Cesaria, hemodynamic

\section{ABSTRAK}

Latar belakang: pada pasien preeklampsia berat intubasi merupakan tindakan yang berbahaya karena berkaitan dengan menejeman jalan napas dan gejolak hemodinamik yang mungkin terjadi. Anestesi spinal banyak dihindari berkaitan dengan resiko hipotensinya namun beberapa penelitian telah menunjukkan bahwa anestesi spinal adalah aman bagi ibu maupun janin . perdebatan tentang pengaruh anestesi umum dan anestesi spinal terhadap Apgar score adalah sesuatu yang menarik. Beberapa penelitian menunjukkan bahwa tidak ada perbedaan anestesi pada keduanya namun pada penelitian lainnya dikatakan bahwa dengan apresiasi umum akan menghasilkan anestesi yang lebih rendah daripada anestesi spinal.

Tujuan : untuk membandingkan pengaruh anestesi umum dan anestesi spinal terhadap anak yang dilahirkan oleh ibu dengan sectio caesaria karena preeklampsia berat. 
Metode : merupakan penelitian eksperimental dengan desain penelitian prospective randomized control trial, kelompok penelitian dibagi menjadi dua (n:8), kelompok I merupakan kelompok yang mendapat anestesi umum dengan pentothal dosis $5 \mathrm{mg} / \mathrm{bb}$ dan pelumpuh otot suksinilkholis dosis $1.5 \mathrm{mg} / \mathrm{bb}$

Kesimpulan : Apgar score pada kelompok anesthesi spinal lebih tinggi daripada anestesi umum pada pasien sectio caesaria karena preeklampsia berat, tetapi secara klinis berdasarkan kategori Apgar score kedua kelompok sama

Kata kunci : preeklampsia, Apgar score, anestesi spinal, sectio cesaria, hemodinamik

\section{PENDAHULUAN}

Kurang lebih 50.000 ibu meninggal karena preeklampsia tiap tahun diseluruh dunia dan hipertensi pada kehamilan menyebabkan 15\%-20\% kematian ibu dan kurang lebih $30 \%$ bayi yang dilahirkan mengalami asfiksia selama persailinan dan IUFD (intrauterine fetal death sebesar $12 \%$ kematian perinatal terjadi karena asfiksia. Hipertensi merupakan penyebab ketiga kematian ibu di USA setelah tromboembolisme dan pendarahan. ${ }^{1,2}$

Sebuah penelitian yang dilakukan di Yogyakarta mendapatkan bahwa preeklampsia akan meningkatkan resiko terjadinya asfiksia berat sebesar 15 kali dibanding kehamilan normotensi, sedangkan untuk terjadinya asfiksia sedang meningkat 2,9 kali. $^{3}$

Asfiksia terjadi bila pada saat neonatus lahir mengalami gangguan gas dan transport $\mathrm{O} 2$ sehingga menderita kekurangan persediaan $\mathrm{O} 2$ dan kesulitan mengeluarkan CO2. Salah satu penyebab terjadinya asfiksia adalah adannya penurunan perfusi uteroplasenta akibat tindakan anestesi yang diberikan.

Pada waktu yang lampau istilah hipertensi selama kehamilan masih membingungkan namun demikian The National High Blood
Pressure Education Program Working Group telah merekomendasikan bahwa istilah hipertensi gestasional diganti dengan pregnancy-induced hypertension untuk mendiskripsikan naiknya tekanan darah disertai proteinuria. Setelah kehamilan 20 minggu dan dan kemudian menurun pada post partum, sebanyak $25 \%$ wanita dengan hipertensi gestasional akan timbul proteinuria dan sindrom preeklampsia. $^{1}$

Preeklampsia merupakan sekumpulan gejala yang terdiri dari hipertensi dan proteinuria setelah kehamilan berumur 20 minggu. 1stilah eklampsia digunakan bila sindrom preeklampsia melibatkan system saraf pusat sehingga berakibat kejang. Istilah HELLP Syndrome digunakan pada preeklampsia dengan hemolysis elevated liver enzymes, and low platelet meskipun kaitan antara preeklampsia dengan HELLP syndrome tidak jelas $1,2,3$

Preeklampsia terjadi pada 5\% sampai 9\% dari semua kehamilan meskipun prevalensi berbeda-beda ditiap Negara. Di United States 7\%-10\% wanita menderita preeklampsia, di Singapura 0,13-6,6\%, sedangkan di Indonesia 3,4$8,5 \%$ dan ini menyebabkan peningkatan morbiditas dan mortalitas ibu dan 
neonatus . Antara tahun 1979 dan 1986 insidensi preeklampsia rneningkat dari 2,4 per 1000 persalinan, menjadi 5,2 per 1.000 persalinan di USA. Pada penelitian terhadap 40.124 kelahiran yang berkaitan dengan kematian ibu setelah kehamilan 20 minggu di USA antara 1979 dan 1992. Telah dilaporkan bahwa rata-rata kematian ibu karena preeklampsia atau eklampsia adalah 1.5 kematian dari 100.000 kelahiran hidup. ${ }^{1,4}$ Sectio caesaria merupakan metode untuk melahirkan bayi melalui irisan pada abdomen dan uterus. Asal mula nama ini tidak jelas walaupun secara luas diyakini bahwa nama ini berasal dari nama Julius Caesar walaupun Julius Caesar tidak dilahirkan dengan metode ini. Mungkin nama ini berasal dari peraturan yang dahulu digunakan yaitu berdasar undangundang Julius Caesar. Berdasarkan Center for Disease Control and Prevention (CDC) lebih dari 700.000 orang menjalani sectio caesaria yang pertama dan 400.000 wanita menjalani sectio caesaria berulang tiap tahun. Jumlah total sectio caesaria adalah 29\% selama tahun 2004. Wanita dengan preeklampsia menunjukkan peningkatan untuk dilakukan pengakhiran kehamilan dengan sectio caesaria, dalam satu penelitian didapat $83 \%$ yang didiagnosis preeklampsia menjalani sectio caesaria. $^{2}$

Beberapa pasien yang memerlukan tindakan sectio caesaria tentunya memerlukan penatalaksanaan anestesi. Karena bahaya yang mungkin timbul berkaitan dengan manajemen jalan napas dan gejolak hemodinamik pada saat intubasi maka anestesi umum dipilih bila ada kontra indikasi terhadap anestesi regional. Anestesi epidural digunakan pada saat pasien dengan preeklampsia berat, meskipun anestesi spinal banyak dihindari berkaitan dengan resiko hipotensinya namun dari beberapa penelitian telah menunjukkan bahwa efek anestesi spinal dan epidural terhadap hemodinamik sama. Perdebatan tentang pengaruh anestesi umum dan anestesi spinal terhadap Apgar score adalah sesuatu yang menarik. Beberapa penelitian menunjukkan bahwa tidak ada perbedaan Apgar score pada keduanya namun pada penelitian lainnya dikatakan bahwa dengan anestesi umum akan menghasilkan Apgar score yang lebih rendah daripada anestesi spinal.

Telah dilakukan penelitian tingkat stress hormone selama anestesi. Pada Kelompok yang dilakukan anestesi umum, adrenocorticotrophic hormone (ACTH) dan betaendorphin meningkat secara bermakna pada saat insisi kulit, tetapi perubahan ini tidak terjadi pada anestesi epidural. Epinefrin dan norepinefrin plasma meningkat secara bermakna pada saat insisi kulit untuk pasien dengan anestesi umum sedangkan anestesi epidural perubahannya tidak bermakna. Anestesi regional yang digunakan dapat menggunakan anestesi epidural atau anestesi spinal karena keduanya menunjukkan efek hermodinamik yang stabil dan tidak bermakna. ${ }^{1,5,6}$

Pada wanita dengan preeklampsia, anestesi spinal mempunyai beberapa keuntungan yaitu menghindari kesulitan intubasi pada anestesi umum dan mencegah gejolak intubasi, onset yang 
cepat, lebih mudah dikerjakan, lebih terpercaya jika dibandingkan dengan anestesi epidural, mempunyai resiko yang lebih kecil dalam menyebabkan trauma di ruang epidural sehingga menurunkan resiko hematom. ${ }^{1,5}$

Pemeriksaan penunjang dan penilaian dalam penatalaksanaan asfiksia, dapat dilakukan dengan : pemantauan janin (klinik dan kardiotokografi), analisis gas darah, USG kepala, Computed Tomografi, MRI, EEG dan Apgar score. ${ }^{7}$

Apgar score merupakan metode untuk melakukan penilaian terhadap bayi baru lahir secara cepat. Penilaian tersebut meliputi lima komponen yang dengan mudah dpt dilakukan. Kelima komponen itu meliputi laju jantung, usaha bernapas, tonus otot, refleks dan warna kulit, dan reflek tergantung dari maturitas fisiologi bayi. Bayi preterm yang sehat tanpa riwayat asfiksia mungkin saja mendapat score yang rendah karena imaturitasnya. Sejumlah faktor pada fetus dipengaruhi oleh penurunan konsentrasi oksigen yang dihirup oleh ibu, penurunan aliran darah uterus, penurunan aliran darah umbilikus, emboli uteroplasenta, pendarahan pada ibu, kombinasi dari hipoksemia dan hipotensia.

\section{METODE}

Penelitian ini merupakan penelitian eksperimental dengan desain penelitian prospective randomized control trial, kelompok penelitian dibagi menjadi dua sebagai berikut, Kelompok I mendapat anestesi umum, yang rnerupakan kelompok kontrol, Kelompok II mendapat anestesi spinal.Tempat penelitian adalah instalasi bedah sentral dan ruang operasi UGD Sakit Umum Pusat Dr. Kariadi Semarang. Waktu penelitian adalah 4 bulan sejak usulan di setujui.

Kriteria inklusi dari penelitian ini adalah pasien dengan preeklampsia berat yang akan menjalani SC, tidak ada riwayat alergi dengan obat-obat anestesi yang akan diberikan, kehamilan aterm, sedangkan Kriteria eksklusi dari penelitian ini adalah pasien menolak untuk ikut dalam penelitian, kontraindikasi untuk dilakukan anestesi umum atau anestesi spinal, BMI $>35 \mathrm{~kg} / \mathrm{m}^{2}$, mallampati $>2$, koagulasi yang abnormal, trombositopeni (trombosit $75 \times 10^{9} / 1$ ), SIRS/Sepsis, deformitas tulang belakang, kehamilan kembar, fetal distress, partus lama, bayi preterm atau serotinus, penderita diabetes mellitus, perdarahan antepartum dan perdarahan intrapartum, ruptur uteri.

Jumlah sampel yang diperlukan untuk penelitian ini adalah 16 sampel, yang dibagi menjadi 2 kelompok yaitu kelompok I (anestesi umum) dan kelompok II (anestesi spinal), masingmasing kelompok berjumlah 8 sampel. Randomisasi dilakukan sebelum operasi. Penderita dibagi menjadi dua kelompok, yaitu kelompok I dan II. Kelompok II mendapatkan anestesi spinal dengan bupivakain $0,5 \%$ hiperbarik $12,5 \mathrm{mg}$, fentanil 25 ug. Sebelum diberikan anestesi spinal diberikan pemberian koloid HES $6 \%$ dalam larutan berimbang sebanyak $500 \mathrm{ml}$, kelompok I mendapatkan anestesi umum dengan pentothal $5 \% 5 \mathrm{mg} / \mathrm{kg} \mathrm{bb}$, suksinilkholin $1,5 \mathrm{mg} / \mathrm{kgbb}$ kemudian dilakukan intubasi 1 menit kemudian, analgetik diberikan tramadol $2 \mathrm{mg} / \mathrm{kgbb}$, 
rumatan anestesi dengan menggunakan $50 \% \quad \mathrm{~N}_{2} \mathrm{O}$ dalam $\mathrm{O} 2$ dan 0,75-1,5\% isoflurane. Setelah bayi lahir dilakukan penilaian Apgar score oleh dokter anak/ residen anak.

Data yang terkumpul dibagi, menjadi dua kelompok. Yaitu kelompok I yang mendapatkan anestesi umum dan kelompok II yang mendapatkan anestesi spinal. Data-data tersebut meliputi data demografi dasar, status obstetrik, umur kehamilan, hemoglobin ibu, gula darah sewaktu melahirkan, hemodinamik ibu, berat badan bayi baru lahir dan Apgar score.

\section{HASIL}

Pada Tabel 1, Rerata (simpangan baku) umur ibu, kelompok I, kelompok II berturut-turut adalah 26,75 (7,09) tahun dan 29,63) tahun. Keadaan tersebut berbeda tidak bermakna antara kedua kelompok $(p=0,408)$. Umur ibu pada kedua kelompok sama.

Rerata (simpangan baku) umur kehamilan kelompok I dan kelompok II berturutturut adalah $37,25 \quad(1,58)$ minggu dan $38,00 \quad(1,60)$ minggu, sehingga umur kehamilan pada kedua kelompok berbeda tidak bermakna $(p=0,328)$ Umur kehamilan antara kelompok I dan II adalah sama. Rerata (simpangan baku) kadar hemoglobin $(\mathrm{Hb})$ kelompok I dan kelompok II berturut-turut adalah 10,87 $(0,63) \mathrm{g} \%$ dan 11,16 $(1,04) \mathrm{g} \%$. Kadar $\mathrm{Hb}$ pada dua kelompok berbeda tidak bermakna $(p=0,516)$, sehingga kadar $\mathrm{Hb}$ pada kedua kelompok adalah sama.

Rerata (simpangan baku) kadar gula darah sewaktu (GDS) kelompok I dan Kelompok
II berturut-turut adalah 103,50 $(20,87)$ $\mathrm{mg} / \mathrm{dL}$ dan 102,75 $(8,88) \mathrm{mg} / \mathrm{dL}$. Kadar GDS antara kedua kelompok berbeda tidak bermakna $(p=0,927)$, sehingga kadar GDS antara kedua kelompok adalah sama. Demikian juga berdasarkan indikasi $\mathrm{c}=$ section kedua kelompok berbeda tidak bermakna $(p=0,41)$, sehingga berdasarkan indikasi sectio caesaria kedua kelompok adalah sama.

Rerata (simpangan baku) waktu insisilahir kelompok I dan Kelompok II berturut -turut adalah 7,25 $(0,46)$ menit dan 7,5 $(0,93)$ menit. Kedua kelompok menunjukkan adanya perbedaan yang tidak bermakna waktu insisi-lahir $(p=0,574), \quad$ sehingga berdasarkan waktu insisi-lahir kedua kelompok adalah sama. Rerata (simpangan baku) berat bayi lahir kelompok I dan kelompok II berturutturut adalah 2869 (266) gram dan 2981 (474) gram. Hasil uji beda menunjukkan bahwa terdapat perbedaan yang tidak bermakna berat bayi lahir antara kedua kelompok $(p=0,568)$.

Rerata (simpangan baku) waktu insisilahir kelompok I dan Kelompok II berturut -turut adalah 7,25 $(0,46)$ menit dan 7,5 $(0,93)$ menit. Kedua kelompok menunjukkan adanya perbedaan yang tidak bermakna waktu insisi-lahir $(p=0,574), \quad$ sehingga berdasarkan waktu insisi-lahir kedua kelompok adalah sama. Rerata (simpangan baku) berat bayi lahir kelompok I dan kelompok II berturutturut adalah 2869 (266) gram dan 2981 (474) gram. Hasil uji beda menunjukkan bahwa terdapat perbedaan yang tidak bermakna berat bayi lahir antara kedua kelompok $\quad(p=0,568)$. Berat bayi lahir 
antara kedua kelompok adalah sama (tabel 2).

Dari grafik 1 dapat dilihat pada kelompok I hanya terdapat dua sampel (25\%) dengn riwayat partus satu kali, sedangkan sisanya belum pernah melahirkan sebelumnya. Sebaliknya pada kelompok II terdapat lima sampel (62,5\%) dengan riwayat partus satu kali, sedangkan sisanya belum pernah melahirkan sebelumnya.

Rerata (simpangan baku) Apgar score menit ke 1,5. 10 kelompok I dan kelompok II berturut-turut adalah 7,00 $(1,07), 7,88(0,84), 9,00(0,76)$ dan 8,63 $(0,52), 9,50 \quad(0,53), 9,88(0,35)$. Terdapat perbedaan bermakna Apgar score menit ke 1,5 dan 10 antara kelompok I dan II. Apgar score menit ke-1, 5,10 pada kelompok II lebih tinggi daripada kelompok I (tabel 3).

Berdasarkan ketegori klinis Apgar score dikategorikan menjadi 3 yaitu Apgar score 0 - 3 (asfiksia berat), Apgar score 4 -6 (asfiksia ringan), Apgar score $7-10$ (normal). Pada kelompok I menit ke -1 ada sampel yang masuk kategori asfiksia ringan sebanyak 3 sampel, sedangkan pada menit ke - 5 dan 10 semua sampel masuk dalam kategori normal.

Pada kelompok II semua sampel adalah normal, baik pada menit ke - 1, menit ke 5 , maupun menit ke -10 . berdasarkan uji beda terdapat perbedaan tidak bermakna antara dua kelompok baik pada menit ke $1(\mathrm{p}=0,234)$, menit ke $-5(\mathrm{p}=1,00)$ dan menit ke $-10(\mathrm{p}=1,00)$, sehingga bedasarkan kategori klinis kedua kelompok sama

Hipotensi berdasarkan tekanan darah sistolik menunjukkan bahwa semua sampel kelompok I tidak ada yang hipotensi sedangkan pada kelompok II terdapat dua sampel (25\%) yang hipotensi dan sisanya (75\%) tidak hipotensi. Sementara itu apabila hipotensi berdasarkan MAP, maka terdapat seorang sampel (12,5\%) dari kelompok I yang bipotensi dan tiga sampel $(37,5 \%)$ dari kelompok II (grafik 2)

Berdasarkan uji Fisher's Exact menunjukkan bahwa kejadian hipotensi berdasarkan tekanan darah sistolik dan MAP pada kedua kelompok berbeda tidak bermakna $(p=0,233)$ dan $(p=0,285)$ kedua kelompok sama

\section{PEMBAHASAN}

Perdebatan tentang anestesi spinal pada preeklamasia berat saat ini telah ditinggalkan. Penelitian yang telah dilaksanakan di Perancis pada tahun 2003 menunjukkan bahwa anestesi spinal pada pasien preeklampsia berat menunjukkan bahwa anestesi spinal pada pasien preeklampsia berat menunjukkan hipotensi yang lebih rendah daripada anesthesia spinal pada pasien sectio caesaria tanpa preeklampsia. Resiko hipotensi enam kali lebih rendah pada pasien dengan preeklampsia berat dari pada pasien tanpa preeklampsia. $^{5}$

Ada dua hal yang mengatur tekanan darah yaitu tonus vaskuler yang diperantarai oleh jalur simpatis dan jalur endothelial jalur simpatis menuju pembuluh darah berubah dengan tindakan anestesi spinal pada pasien preeklampsia berat maupun pada pasien tanpa preeklampsia. Perhatian tertuju pada jalur endothelial. Akibat kegagalan invasi trophoblast menyebabkan penurunan perfusi utero plasenta. Plasenta wanita dengan preeklampsia menunjukkan adanya peningkatan frekuensi infark dan perubahan morfologi karena adanya proliferasi sitotrofoblast yang abnormal dan adanya peningkatan pembentukakan syncytial knots.

Endothelium vaskuler mempunyai beberapa fungsi penting termasuk 
Tabel 1. Umur, umur kehamilan, kadar Hb dan kadar GDS, indikasi sectio caesaria

\begin{tabular}{llll}
\hline Variabel & \multicolumn{2}{l}{ Kelompok Perlakuan } & P \\
\hline & Kelompok I & Kelompok II & \\
\hline Umur (tahun) & $26,75(7,09)$ & $29,63(6,37)$ & $0,408^{1}$ \\
Umur Kehamilan (minggu) & $37,25(1,58)$ & $38,00(1,60)$ & $0,328^{2}$ \\
Kadar Hemoglobin (g\%) & $10,87(0,63)$ & $11,16(1,04)$ & $0,516^{1}$ \\
Kadar GDS (mg/dL) & $103,50(20,87)$ & $102,75(8,88)$ & $0,927^{1}$ \\
Indikasi sectio caesaria & & & \\
Panggul sempit & 0 & 1 & $0,411^{3}$ \\
Disproporsi kepala & 0 & 0 & \\
Panggul & & & \\
Malpresentasi & 4 & 2 & \\
Partus tak maju & 4 & 5 & \\
\hline
\end{tabular}

Keterangan: ${ }^{1}$ : independen $t$ test

2: mann whitney test

3: chi-square test

Tabel 2. Waktu insisi- lahir dan berat bayi lahir

\begin{tabular}{cccc}
\hline Variabel & \multicolumn{2}{c}{ Kelompok perlakuan } & $\mathrm{p}$ \\
\cline { 2 - 3 } & Kelompok I & Kelompok II & \\
\hline Insisi-lahir (menit) & $7,25(0,46)$ & $7,50(0,93)$ & $0,574^{2}$ \\
Berat bayi lahir (gram) & $2868(266)$ & $2981(474)$ & $0,568^{1}$ \\
\hline
\end{tabular}

Ket :

${ }^{1}=$ independent $\mathrm{t}$ test

${ }^{2}=$ mann whitney test

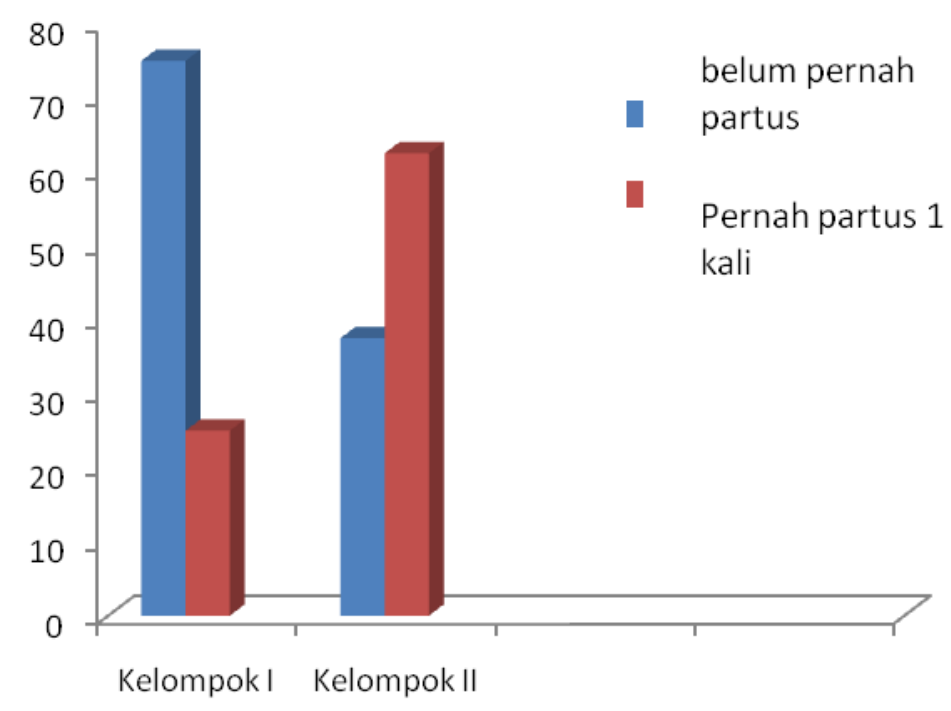

Grafik 1. Distribusi frekuensi (dalam \%) riwayat partus di antara kedua kelompok 
mengontrol tonus vaskuler dengan melepaskan beberapa zat yang bersifat vasokonstriktor dan vasodilator dan mengatur fungsi antikoagulasi, antiplatelet dan fibrinolisis. Hal ini menunjukkan bahwa pelepasan beberapa zat dari palsenta sebagai respon dari iskemia plasenta menyebabkan disfungsi endothel sirkulasi ibu. Disfungsi endothel merupakan tanda awal preeklampsia dan hal ini merupakan penyebab dan bukan akibat dari ganggguan kehamilan. ${ }^{8}$

Selama kehamilan normal terjadi peningkatan aktivitas endothelial Nitric Oxide Synthase (NOS) dan Cyclooxigenase (COX) dan peningkatan produksi nitric oxide (NO), prostacyclin (PG12), dan endothelium-derived hyperpolarizing factor (EDHF). NO meningkatkan cGMP dan PG12 Meningkatkan c GMP dan PG12 meningkatkan cAMP pada otot polos, $\mathrm{Ca}^{2+}$ intraseluler mengalami penurunan dan miofilamen menjadi sensitif terhadap $\mathrm{Ca}^{2+}$. Demikian juga EDHF akan membuka $\mathrm{K}^{+}$channels, sehingga menyebabkan membran otot mengalami hiperpolarisasi. hal ini menyebabkan relaksasi otot polos dan penurunan tahanan perifer serta penurunan tekanan arteri. Pada preeklampsia terjadi meningkatkan pelepasan sitokin plasenta yang menghambat produksi endotheliumderived relaxing factor sehingga terjadi penurunan relaksasi otot polos. Sitokin juga merangsang pelepasan endotheliumderived contracting factor seperti endothelin-1 (ET-1) dan tromboksan A2 (TXA2) dan mengaktifkan reninangiotensin system (RAS) di ginjal sehingga meningkatkan ANG II. Endothelin-1, TXA2, dan ANG II merangsang reseptor spesifik di otot polos sehingga meningkatkan $\mathrm{Ca}^{2+}$ intraseluler, aktifitas protein kinase $\mathrm{C}$ (PKC) dan hal ini menyebabkan kontraksi otot polos, dan meningkatkan tahanan perifer serta tekanan arteri. ${ }^{8}$

Demikian juga penelitian di Thailand pada tahun 2005 telah membandingkan anestesi spinal dan anestesi epidural pada preeklampsia, dari penelitian tersebut didapatkan bahwa insidensi hipotensi pada anestesi spinal lebih tingi daripada anestesi epidural namun durasi hipotensi pada kedua kelompok singkat. Penggunaan efedrin untuk mengatasi hipotensi lebih banyak pada anestesi spinal namun demikian hipotensi yang terjadi mudah untuk diatasi pada kedua kelompok. Bayi yang dilahirkan kemudian dilakukan peniliaian dengan Apgar score maupun analisa gas darah dari arteri umbilikus dan ternyata keduanya sama pada kedua kelompok. ${ }^{9}$

Perencanaan tindakan anestesi pada sectio caesaria harus senantiasa memperhatikan keselamatan ibu maupun anak. Anestesi umum maupun anestesi regional, termasuk anestesi spinal, epidural maupun combine spinal epidural, dapat dilakukan pada pasien yang akan menjalani sectio caesaria. Sebagian besar operasi sectio caesaria yang dilakukan di Amerika Serikat menggunakan anestesi regional, dan anestesi regional yang sering digunakan adalah anestesi spinal. ${ }^{10}$

Pertanyaan mengenai seberapa besar pengaruh anesesi umum dibandingkan anestesi regional terhadap Apgar score bayi baru lahir merupakan satu hal yang menarik, bahkan hal ini telah diteliti oleh beberapa peneliti, dan umumnya merupakan penelitian retrospektif terutama pada operasi-operasi elektif. Beberapa peneliti melaporkan bahwa tidak ada perbedaan antara anestesi umum dan anestesi regional namun beberapa peneliti melaporkan bahwa Apgar score yang rendah telah terjadi pada pasien sectio caesaria dengan anestesi umum. ${ }^{10}$ 
Sementara itu hasil pada penelitian ini menunjukkan bahwa Apgar score pada menit pertama dengan anesesi spinal karena preeklampsia berat menunjukkan rerata yang lebih tinggi dan perbedaan rerata Apgar score antara anestesi umum dan menunjukkan perbedaan yang bermakna dengan $p=0,007 \quad(p<0,05)$, demikian juga pada menit kelima maupun menit kesepuluh Apgar score pada pasien preeklamasia berat yang mendapatkan anestesi spinal mempunyai rerata yang lebih tinggi daripada anestesi umum dan terdapat perbedaan yang bermakna antara kedua kelompok berturut-turut didapatkan nilai $\mathrm{p}=0,002$ dan $\mathrm{p}=0,028(\mathrm{p}<0,05)$. Dari keseluruhan sampel penelitian didapatkan bahwa Apgar score $\geq 7$, sehingga kondisi bayi yang dilahirkan semuanya masuk dalam kelompok yang sama yaitu kelompok normal. Hasil penelitian ini sesuai dengan penelitian sebelumya yang menyatakaan bahwa umumnya bayi yang dilahirkan oleh ibu dengan preeklampsia berat lahir pada saat aterm dengan berat badan yang normal, morbiditas dan mortalitas yang lebih kecil jika dibandingkan dengan literatur yang telah ada sebelumnya. Apgar score merupakan metode yang sederhana dan mudah untuk diulang dalam menilai kondisi bayi yang baru dilahirkan secara cepat dan ringkas. Tes Apgar bertujuan utuk menilai kondisi fisiologis bayi secara cepat apakah bayi tersebut segera memerlukan perawatan medis dan tidak untuk menilai kesehaan bayi dalam jangka panjang. ${ }^{11,12}$

Insidensi hipotensi lebih tinggi pada kelompok yang mendapat anestesi spinal yaitu sebesar 37,5\% dibanding kelompok yang mendapatkan anestesi umum yaitu sebesar 12,5\%. Perbedaan insidensi hipotensi ini tidak berbeda bermakna antar kedua kelompok. Hasil penelitian ini sesuai dengan hasil penelitian Visalyaputra yang menyatakan bahwa insidensi hipotensi pada preeklampsia yang diberikan anestesi spinal lebih tinggi. Walaupun insidensi hipotensinya lebih tinggi namun Apgar score pada kelompok anesthesia spinal baik hal ini diduga karena durasi hipotensinya hanya singkat, mudah dalam penatalaksanaanya serta bayi mempunyai mekanisme kompensasi untuk tetap mempertahankan kecukupan oksigennya yaitu dengan meningkatkan laju nadi bayi sehingga anestesi spinal aman untuk diberikan pada ibu dengan preeklampsia., ${ }^{6,9}$

Nilai Apgar score yang rendah pada menit pertama saja tidak menunjukkan hasil akhir dari bayi. Apgar score yang rendah pada menit pertama menunjukkan bahwa bayi baru lahir memerlukan perhatian medis tetapi bukan merupakan indikasi bahwa bayi tersebut akan mempunyai masalah kesehatan dalam jangka panjang. Pada anestesi umum obat induksi yang digunakan dalam hal ini thiopental dapat menyebabkan depresi ringan aktivitas bayi yang sifatnya sementara sehingga dapat berakibat rendahnya Apgar score pada menit pertama. Sementara obat induksi yang lain yaitu suksinikholin tidak menunjukkan adanya transfer plasenta kecuali dosis yang diberikan lebih dari $300 \mathrm{mg}$. dari penelitian analisis retrospektif disimpulkan bahwa Apgar score pada menit kelima merupakan prediktor yang valid untuk menilai resiko kematian bayi baru lahir. Apgar score pada menit kelima sampai 10 menit menunjukkan bahwa kondisi bayi normal, Apgar score 4,5,6 (asfiksia ringan) biasanya memerlukan bantuan medis misalnya dapat diberikan oksigen dan bantuan napas, sedangkan Apgar score kurang dari 4 maka bayi tersebut memerlukan resusitasi. ${ }^{13}$

Penelitian ini mempunyai keterbatasan diantaranya adalah sampel penelitian yang kecil, sehingga perlu sampel yang lebih besar agar diperoleh hasil yang lebih 
Tabel 3. Apgar score

\begin{tabular}{|c|c|c|c|}
\hline & \multicolumn{2}{|c|}{ Kelompok Perlakuan } & \multirow[t]{2}{*}{$\mathbf{P}$} \\
\hline & Kelompok I & Kelompok II & \\
\hline Apgar score menit ke-1 & $7,00(1,07)$ & $8,63(0,52)$ & $0,007^{2}$ \\
\hline Apgar score menit ke-5 & $7,88(0,84)$ & $9,50(0,53)$ & $0,002^{2}$ \\
\hline Apgar score menit ke 10 & $9,00(0,76)$ & $9,88(0,35)$ & $0,028^{2}$ \\
\hline
\end{tabular}

Ket $:{ }^{2}$ mann whitney test

Tabel 4. Perbedaan klinis Apgar score

\begin{tabular}{|c|c|c|c|c|}
\hline \multicolumn{2}{|c|}{ Kategori Apgar score } & \multicolumn{2}{|c|}{ Kelompok Perlakuan } & \multirow[t]{2}{*}{$\mathbf{P}$} \\
\hline & & Kelompok I & Kelompok II & \\
\hline \multirow{3}{*}{ Menit ke - 1} & Asfiksia berat & 0 & 0 & $0,234^{2}$ \\
\hline & Asfiksia ringan & 3 & 0 & \\
\hline & Normal & 5 & 8 & \\
\hline \multirow[t]{3}{*}{ Menit ke - 5} & Asfiksia berat & 0 & 0 & $1^{2}$ \\
\hline & Asfiksia ringan & 0 & 0 & \\
\hline & Normal & 8 & 8 & \\
\hline \multirow[t]{3}{*}{ Menit ke - 10} & Asfiksia berat & 0 & 0 & $1^{2}$ \\
\hline & Asfiksia ringan & 0 & 0 & \\
\hline & Normal & 8 & 8 & \\
\hline
\end{tabular}

Ket : ${ }^{2}$ mann whitney test

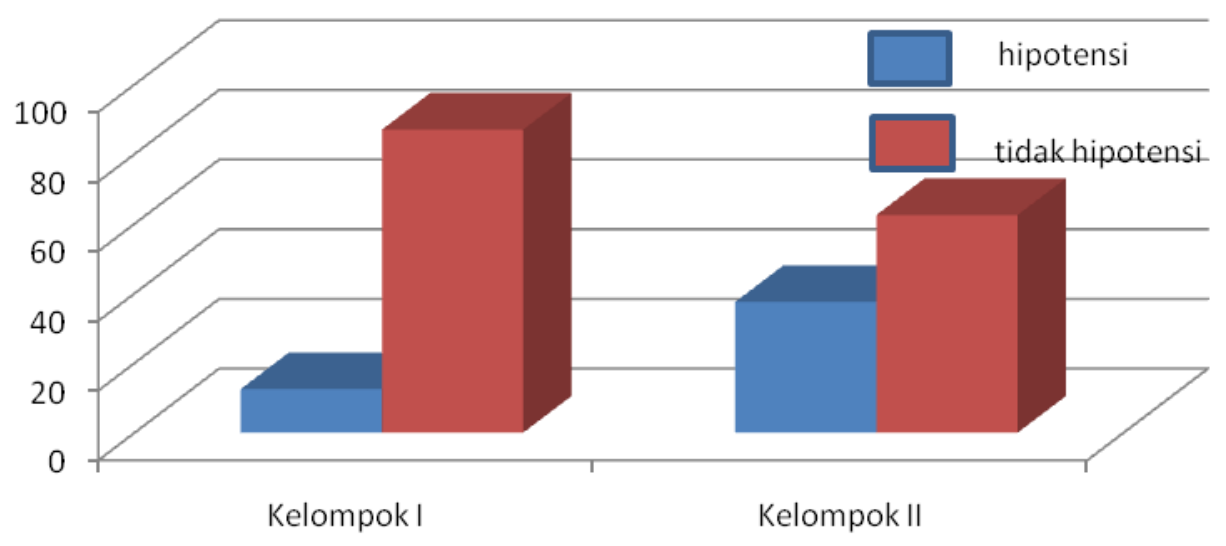

Grafik 2. Distribusi frekuensi (dalam 100\%) riwayat hipotensi berdasarkan MAP diantara kedua kelompok 
akurat. Disamping itu sectio caesaria karena preeklampsia berat sebagian besar dikerjakan dalam status darurat (cito), maka untuk operator, dokter anestesi, maupun dokter anak sulit untuk dikerjakan oleh tim yang sama karena disesuaikan dengan jadwal jaga masingmasing bagian, sehingga keterbatasan diatas akan merupakan bias dalam penelitian ini.

\section{SIMPULAN}

Apgar score bayi yang lahir dari pasien sectio caesaria karena preeklampsia berat pada kelompok anestesi spinal lebih tinggi daripada anestesi umum, tetapi secara klinis berdasarkan kategori Apgar score kedua kelompok sama.

\section{DAFTAR PUSTAKA}

1. Gambling, RG, Hypertensive disorders. In :Chesnut DH. Obstetric anesthesia principles and practice 3 rd . ed. Philadelphia : Elsevier Mosby, 2004 :795-830

2. Hypertensive disorder in Pregnancy : Anesthetic implication and management. Available from :URL http ://www. Freemedeme.com/eme/article.efm mode $=$ article full view $\&$ cme id $=13$

3. Hermatno. Factor Resiko asfiksi neonatorum di RSUP dr. Sardjito Yogyakarta; Bagian IKA FK UGM//RSUPdr. Sardjito; 1992

4. Granger JP, Barbara TA, Llamas MT, Bennett WA, Khalil RA Pathophysiology of hypertension during preeclampsia linking placental ischemia with endothelial dysfunction. Available from URL: http:// www.hyper.ahojourplas.org.egi/content/ full/97/3/867

5. Aya GM, mangin R, Vialles N, Ferrer JM, Robert C, Ripart J, Coussaye JE. Patients with severe preeclampsia experience less hypotension during spinal anesthesia for elective cesarean delivery than healthy parturient; A prospective cohort comparison. Available from URL : http://www/aneshesia. Analgesia.org/egi/content/full/97/3/867

6. MacArhur A, Anesthesia for severe hypertensive disease of pregnancy and ischemic heart from URL : $\mathrm{http}: / /$ www.anesthesia analgesia.org/egi/reprint/101/3/862.

7. Chair I, Ensefalopati biopsies iskemikpada bayi baru lahir. Dalam :reasy RK, Resnik R eds Maternal Fetal Medicine. 3 rd ws, USA;WB Saunders, 1994: 28

8. Khalil RA, Granger JP. Vascular mechanisms of increased arterialpressure in preeclampsia :lessons from animal medels. Availale from URL : http:// ajpregu.physiology.org/cegi/content/full/283/1/ R29/BIBL

9. Visalyaputra $\mathrm{S}$, Rondonant $\mathrm{O}$, somboonvinoon W, Tantivitayatan K, Thientong S. SaengchoteW. Spinal versus epiduralanesthesisa for cesarean deligery in severa preeclamsia : a prospective randomizedmultycenter study. Avialableform URL :http: www.medscape.com/ viewarticle/520775

10. Khademis. The effect of anesthesia on apgar. Availabelform URL: Http:// www.medscape.com/viearticle /520775

11. Bellis M. Apgar Scoring for Newborn. Available form UR:http//en. Wikipedia.org/ wiki/Apghar score.

12. Nava F., Roblesn P., Padilla L. Neonatal Outcome in women with severe preeclamsia. Available from URL : $\underline{\text { http:// }}$ www.imbiomed,com.mx/Inper/Prv12n4/ english/Zor84-01.html

13. American Academy of Pediatrics, Committee on Fetus and Newborn, American College of Obstetricians and sGyanccologist and Committec on Obstetric Practice. The apgar score.available from URL : http://aapopolicy. Aappublications . org/cgi/content/full/ pediatrics; $1174 / 1444$ 